\section{A SUCCESSFUL OUTCOME OF TWIN PREGNANCY IN PATIENT WITH SYSTEMIC LUPUS ERYTHEMATOSUS - A CASE REPORT}

Nahreen Akhtar ${ }^{1}$, Sayeeda Sultana ${ }^{2}$, Shahin Akhter Jahan Habib ${ }^{3}$

\section{Abstract:}

A 28 years old lady was admitted in BSMMU with $4^{\text {th }}$ gravida 33 wks. twin pregnancy with preeclampsia and anasarca. She is a known case of SLE for 4 years and was diagnosed at her $3^{\text {rd }}$ pregnancy. At that time her antids DNA titre was 1100IU/ml. She was in prednisolone and aspirin. She was in remission phase and with advice of physician she got pregnancy. She was diagnosed as a case of twin pregnancy at 12 weeks of pregnancy.

\section{Introduction:}

Systemic lupus erythematosus (SLE) is a multisystem autoimmune disorder with a wide spectrum of disease manifestations. It is of interest to obstetricians because it predominantly affects woman of $(10: 1)$ of reproductive age ${ }^{1}$ It is first diagnosed during pregnancy in $10-30$ present cases. ${ }^{2}$ There is chance of flare up specially during first half and maximum in puerperium. It is significant that better out come are achieved in those who conceive when their condition is quiescent and worse for those with unstable disease. Majority of maternal death occur in puerperium, the cause being pulmonary haemorrhage and lupus pueumonitis. ${ }^{2}$ Much of the impaired outcome can be explained as a result of secondary antiphospholipid syndrome with increased risk of IUGR, placental abruptio and preeclampsia. ${ }^{3}$ Presence of auto antibodies to double stranded DNA is highly specific to the diagnosis. ${ }^{2}$ Neonatal lupus syndrome is due to crossing of maternal lupus antibodies (anti SSa and SSb) to the fetus causing hemolytic anaemia, leucopenia and thrombocy topenia. Treatment in pregnancy involves antiplatelet therapy with low dose aspirin and heparin. ${ }^{3}$

\section{Case Report :}

A 28 year old lady of $4^{\text {th }}$ gravida, with no living issue, two abortion and one IUD got admitted in BSMMU on $21^{\text {st }}$ October '08 with $4^{\text {th }}$ gravida 33 wks term pregnancy with preeclampsia and anasarca. She is a known case of SLE for last 4 years. She was diagnosed as a case of SLE at her $3^{\text {rd }}$ pregnancy when she

1. Associate Professor, Fetomaternal Medicine, Obst. \& Gynae, BSMMU.

2. Assistant Professor, Fetomaternal Medicine, Obs \& Gynae, BSMMU

3. Assist Prof. (Obs \& Gynae),SZ Medical College \& Hospital, Bogra. developed malar rash. Her antids antibody titre was 1100IU/ml. She was treated with pred nisolone and aspirin. This treatment was continuing in low dose till this present pregnancy. With this pregnancy she got admitted three times in Mymensingh Medical College Hospital with preeclampsia and ascites. Lastly she was referred to fetomaternal medicine unit, BSMMU for proper management.

On admission her BP was 160/100mg with tab amlodipine, her bedside urine albumin was $3+$. Her serum total protein wan 53g/l, albumin was $14 \mathrm{~g} / \mathrm{l}$ and globulin was 39g/l. Her urinary total protein was $1.04 \mathrm{~g} /$ day. Inj oradexon $12 \mathrm{mg}$ given at $12 \mathrm{hrs}$ apart for lung maturity. On $8^{\text {th }}$ day of admission decision for termination by caesarean section was taken because of severe proteinuria. During caesarean section when a small opening is made at parietal peritoneum 4L fluid was sucked out by sucker. Then two babies delivered, one weighing $1 \mathrm{~kg}$ and another $1.1 \mathrm{~kg}$ both the babies were resuscitated and transferred to neonatal unit. Before and during caesarean section hydrocortisone was given. Later it was changed to Tab prednisolone 20mgm bd. Her oedema subsided but ascites decreases slowly. She was discharged at $11^{\text {th }}$ post operative day with the advice to attend rheumatology clinic. At the time of discharge her BP was normal with anthypertensive, her mild ascites was present and there was also persistant proteinuria.

\section{Discussion :}

SLE is an inflammatory autoimmune disorder that may affect multiple organ system. Many of its clinical manifestations are secondary to the trapping of the antigen antibody complexes in capillaries of visceral structures or to autoantibody mediated destruction of host cells (e.g. thrombocytopenia). The clinical course is marked by spontaneous remission and relapses. Familial occurrence of SLE has been repeatedly documented. The importance of specific genes in SLE is emphasized by the high frequency of certain HLA haplotypes, especially DR2 and DR 3 and null complement alleles. Three types of anti phospholipid antibodies occur. The first causes the biologic false positive tests for syphilis, the second is the lupus anticoagulant, which is a risk factor for venous and arterial thrombosis and miscarriage. It is most commonly identified by prolongation of the activated partial thromboplastin time. Anticardiolipin antibodies are the third type of antiphospholipid antibodies. The course of the disease is unpredictable, with periods of illness (called flares) alternating with remissions. The reported incidence of SLE flares during pregnancy ranges from $13 \%$ to $60 \%$ leading some investigators to believe the flare rate is unchanged while others consider pregnancy as a 
time of vulnerability to increased disease activity. ${ }^{4,5}$ Patient with inactive SLE at conception are less likely to experience flares during pregnancy. ${ }^{4}$ Lupus flare during any trimester or postpartum necessitating close follow up. The flares are generally mild with arthritis and cutaneous manifestations. Patients with preexisting major organ involvement like kidneys need monitoring for renal flare. ${ }^{6}$ Women with SLE have no increased risk of infertility although they are at risk for various complications of pregnancy. The outcome for both mother and child is best when SLE has been under good control for at least six months before pregnancy and when the kidney disease is in remission. This rate is comparable to the number of women who have flares and are not pregnant. In contrast, more than 60 percent of women with active disease at the time of conception have a flare during pregnancy. Pregnancy complications are hypertension, preeclampsia, preterm delivery, unplanned caesarean section, postpartum haemorrhage, venous thromboembolism. The risk is increased in women with high BP, active lupus, lupus nephritis and those with low complement levels, elevated levels of anti DNA antibody, antiphospholipid antibody. All pregnant women with SLE should be tested for the presence of antiphospholipid antibody. Women with persistent, medium or high titre of these antibodies may be at increased risk of fetal loss or other complication. The management of a women with SLE during pregnancy depends upon a number of factors such as her past pregnancy history and whether a not she meets the criteria for antiphospholipid syndrome. Based upon these factors, management may involve treatment with low dose aspirin, an anticoagulant or combination of both. Antimalarials (hydroxychloroquinine) may be helpful in treating rashes and joint symptoms and this is safe during pregnancy. Forty to sixty mg of oral prednisolone is often needed initially; however the lowest dose of corticosteroid that controls the condition should be used. Flares are managed by escalation of treatment like nonsteroidal anti-inflammatory drugs (NSAID) and corticosteroid. Major organ flares (like renal disease) may need institution dose, escalation of azathioprine. Cyclophosphamide is contraindicated in pregnancy. Prophylactic corticosteroid to prevent lupus flares during pregnancy are not recommended. ${ }^{6}$ Recently, several reports of successful maternal and fetal outcome with intravenous and inhaled iloprost treatment at different stages of pregnancy and post partum period have been published nontheless cases of maternal deaths are still not unusual. ${ }^{7}$

\section{References:}

1. Laura Kalayjian, T Murphy Goodwin. Nervous system \& Autoimmune Disorders in pregnancy. In: Alan $\mathrm{H}$ De Cherny, Lauren Nathan. Current Obstetric \& Gynaecologic Diagnosis and Treatment. $10^{\text {th }} \mathrm{ed}$. New York: MC GrawHill; 2007.p 404.

2. D C Dutto. Text book of Obstetrics including perinatology and contraception. $6^{\text {th }}$ ed. New Central Book Agency (P) Ltd. Calcutta, 2005, p, 297.

3. Andrew MC Carthy. Miscellanceous medical disorders. In : Edmonds DK. Dewhurst's Text book of Obstetric and Gynaecology. UK: Blackwell publishing, 2007 ISBN-9781-4051-6111-4, London, p-285.

4. Urowitz MB, Gladman DD, Farewell VT, Stewart J, Mc Donald J: Lupus and pregnancy studies, Arthritis Rheum 1993, 36: 1392-1397.

5. Khamashta MA, Ruiz - Irastorza G, Hughes GR: Systemic Lupus Erythematosus flares during pregnancy. Rheum Dis Clin North Am 1997, 23: 15-30.

6. Ruiz Irastorza G, Lima F, Alves J. et al. Increased rate of lupus flare during pregnancy and the puerperiums : a prospective study of pregnancies. Br J Rheumatol 1, 635:133

7. Easterling TR, Ralph DD, Schmucker BC : Pulmonary hypertension in pregnancy : treatment with pulmonary vasodilator. Obstet Gynecol 1999, 93: 494-498. 